\title{
Impact of phytochemicals and plant extracts on viability and proliferation of NK cell line NK-92 - a closer look at immunomodulatory properties of goji berries extract in human colon cancer cells
}

\author{
Paulina Kwaśnik ${ }^{1, B-D, F \oplus \text {, Marta Kinga Lemieszek }}{ }^{2, A-F \oplus}$, Wojciech Rzeski ${ }^{2,3, A, F}$ \\ ${ }^{1}$ Department of Experimental Hematooncology, Medical University, Lublin, Poland \\ ${ }^{2}$ Department of Medical Biology, Institute of Rural Health, Lublin, Poland \\ ${ }^{3}$ Department of Functional Anatomy and Cytobiology, Maria Curie-Skłodowska University, Lublin, Poland \\ A - Research concept and design, B - Collection and/or assembly of data, C - Data analysis and interpretation, \\ $D$ - Writing the article, E - Critical revision of the article, $F$ - Final approval of article
}

\begin{abstract}
Kwaśnik P, Lamieszek MK, Rzeski W. Impact of phytochemicals and plant extracts on viability and proliferation of NK cell line NK-92 - a closer look at immunomodulatory properties of goji berries extract in human colon cancer cells. Ann Agric Environ Med. 2021; 28(2): $291-299$. doi: $10.26444 / a a e m / 133801$
\end{abstract}

\begin{abstract}
Introduction. Due to the fact that lymphocytes NK (natural killer cells) are the first line of defence of the body against cancer, one of the goals of modern immunotherapy is the enhancement of their natural activities for the effective recognition, detection, and elimination of cancer cells.

Objective. The aim of the study was to evaluate the influence of selected phytochemicals (curcumin and resveratrol) and plant extracts (chlorella and goji berries) on NK cells viability and proliferation, as well as cytotoxic activity against colon cancer - one of the most common cancer worldwide.

Materials and Method. The impact of phytochemicals, viability and proliferation of plant extracts on NK cells was examined in NK-92 cells using both LDH and MTT assays. The immunomodulatory properties of selected compounds were tested against human colon cancer cell line LS180 using the MTT test.

Results. Extracts of chlorella and goji berries significantly increased NK cell proliferation, while curcumin and resveratrol did not affect this process. Curcumin, as well as extracts of chlorella and goji berries, did not impact NK viability, while resveratrol significantly increased it. LDH test revealed the cytotoxic effect of chlorella extract and curcumin in NK-92 cell cultures. On the contrary, goji berries extract significantly decreased LDH level, while resveratrol did not affect the integrity of NK cell membranes. Studies conducted in co-cultures NK cells, also directly eliminated colon cancer cells.

Conclusions. Performed studies revealed immunomodulatory properties of goji berries extract, which improved viability and proliferation of NK cells, and above all, significantly increased their ability to recognize and eliminate colon cancer cells.
\end{abstract}

\section{Key words}

immunomodulation, curcumin, resveratrol, chlorella, goji berries, NK-92, immune enhancement

\section{INTRODUCTION}

Despite the progress that has been made in oncology in recent years, the increasing cancer incidence and mortality of cancer required the search for new, more effective, and above all, safer therapeutic strategies. These assumptions are perfectly met by immunotherapy. Furthermore, at the beginning of the 21st century, the American Society of Clinical Oncology forecast that immunotherapy would dominate cancer treatment, and after 2020 it would be used in the treatment of every second cancer. The basis of immunotherapy is the mobilization and strengthening of the body's own defence mechanisms to fight the diseases. Due to the fact that the first line of the body defence against cancer are lymphocytes NK (natural killer cells) one of the goals of modern immunotherapy is the enhancement and/

Address for correspondence: Marta Kinga Lemieszek, Department of Medical Biology, Institute of Rural Health, Lublin, Poland

E-mail: martalemieszek@gmail.com

Received: 25.09.2020; accepted: 01.03.2021; first published: 11.03.2021 or modification of their natural activities for the effective recognition, detection and elimination of cancer cells $[1$, 2]. There are several well-documented strategies of NK cells use in cancer immunotherapy, including adopted therapy, antibody-dependent cellular cytotoxicity, NK cells stimulation with cytokines, or blocking of NK cells inhibitory receptors [3]. Considering the cost and labour intensity of these strategies, the possibility of using the components of the daily diet to activate NK cells seems to be a noteworthy issue, especially because their immunomodulatory properties was earlier suggested.

Presented study focuses on phytochemicals (curcumin and resveratrol) as well as extracts obtained from plants (chlorella and goji berries) whose immunomodulatory properties have been reported previously. Chlorella was chosen for the research because it has been proven that hydrolyzed Chlorella vulgaris by malted barley enhances the immune function by increasing INF- $\gamma$ and IL-2 levels in human T lymphoblast cell line MOLT-4 [4]. Lyophilized heat-treated C. vulgaris alleviates the side-effects of cyclophosphamide by stimulating 
the immune system, including increased NK cells activity [5]. Furthermore, Chlorella sorokiniana immunomodulatory and anticancer activities have been proven in the mouse colon carcinoma cell line CT26.CL25, and the following human colon carcinoma cell lines: SW620, HT29, COLO 205 and Caco-2 [6]. Additionally, stimulation of cytokines release and nitrogen oxide production in macrophages cell line RAW264.7, in response to polysaccharides of green alga Chlorella ellipsoidea, have been reported $[7,8]$. It has been proved in preclinical trials that the enzymatic protein hydrolyzate from green microalgae C. vulgaris shows an immune-enhancing effect in mice, with a general increase in the number of peripheral blood leukocytes and stimulation of phagocytes [9].

Goji berries were chosen for testing because recent studies have shown that their extracts possess biological activities, including anti-aging, anti-cancer, immunomodulatory and cytoprotective [10]. Studies conducted by Lin et al. revealed that an aqueous Lycium barbarum extract increased phagocytic activity of mouse macrophages cell line RAW 264., as well as stimulated the production of cytokines and nitrogen oxide [11]. Zhu et al. showed that phenolic amides from the nonpolysaccharide fraction of L. barbarum fruit significantly stimulate the proliferation of both B-cells and T-cells in vitro, and proved the strengthening of spleen cells and activation of the immune response by the induction of cytokines, such as IFN-IL-2 and IL-10, in immunodeficient mice [12]. Other preclinical studies proved that polysaccharide extracted from Lycium ruthenicum Murr. fruits was able to protect against cyclophosphamide-induced immunosuppression in mice supplemented with this extract [13].

Curcumin was selected for studies because of its confirmed anti-inflammatory, antioxidant and immunomodulatory effects [14]. Many studies have demonstrated the immunosuppressive effect of curcumin, highlighting its antiinflammatory properties, although Srivastava et al. recalled that there are known cases of curcumin immunostimulation [15]. The immunosuppressive properties of curcumin were reported by Gao et al., who observed, in response to curcumin treatment, impairment of spleen lymphocyte proliferation and stimulation of cytotoxic $\mathrm{T}$ lymphocytes that were unresponsive to activating molecules [16]. Other researchers also report the anti-inflammatory properties of curcumin in the treatment of bronchial asthma [17], suppression of macrophages in the context of inflammation-related diseases [18], and therapeutic potential in experimental autoimmune myasthenia gravis (EAMG) [19].

The last substance selected for research was resveratrol, which is famous for its antioxidant, anticancer and antiinflammatory effects $[20,21]$. The antimicrobial properties of this polyphenol in relation to Haemophilus influenzae and the effectiveness in preventing respiratory infections caused by this pathogen have also been proven. Moreover, this study demonstrated the immunomodulatory properties of resveratrol in response to Haemophilus influenzae lung infections in both human epithelial cell line A549, as well as mice lung tissue [22]. Furthermore, the immunomodulatory effect of resveratrol was confirmed in preclinical trials on piglets infected with rotavirus, wherein the tested compound inhibited TNF- $\alpha$ release and thus maintained immune function by increasing the level of INF- $\gamma$ [23]. Interestingly, a beneficial effect of resveratrol on antioxidant and antiinflammatory systems (SIRT1 and AMPK activation) was reported in rats with polycystic ovary syndrome (PCOS), one of the most common gynecological diseases in women [24]. Next to immuno-enhancement properties, the abovementioned compounds also have anticancer properties, which increases the possibility of their use in oncological immunotherapy.

Chlorella is widely used as a dietary supplement because of its chemopreventive properties. The antiproliferative effect of a lyophilized extract of Chlorella pyrenoidosa has been proven on the HeLa cancer cell line [25]. Karakas et al. revealed the cytotoxic effect of Chlorella protothecoides extract loaded nano-microparticles in a human glioma brain cell line A172 and colorectal cancer cell line HCT116 [26]. Zhang et al. have shown that partially purified exopolysaccharides from the microalgae C. pyrenoidosa inhibited the viability of the human colon cancer cell lines HCT 116 and HCT-8 [27]. Kubatka et al. revealed that $C$. pyrenoidosa powder significantly reduced the survival of human breast adenocarcinoma cell line MCF7 [28].

The proapoptotic and antiproliferative activities of the fruit of $L$. barbarum polysaccharide fractions have been demonstrated in human hepatoma cancer cells SMMC-7721, human breast cancer cells MCF7, and human cervical cancer cells (HeLa) cells [29]. Mao et al. proved the antiproliferative effect of $L$. barbarum polysaccharide against human colon cancer cell lines SW480 and Caco-2 [30]. Another study focused on ethanol extract isolated from the Goji berry (EEGB), demonstrated the proapoptotic and cytostatic effect of the tested compounds in human breast cancer cell line T47D [31]. Studies by Georgiev et al. on L. barbarum's pectin-free fraction have shown their antioxidant and antiproliferative activity in human breast cancer cells MCF7, MDA-MB-231, probably due to the high content of polyphenols [32]. It is noteworthy that murine renal carcinoma cells RCC treatment with the combination of L. barbarum polysaccharides and interferon clearly inhibited the proliferation of Renca cells [33].

Curcumin has also a wide range of chemopreventive and chemotherapeutic properties [34]. Curcumin's anticancer potential associated with its ability to inhibit the cell proliferation was observed in human breast cancer cell lines MCF7 and MDA-MB-231, as well as human liver cancer cells HepG2 [35]. Calibasi-Kocal et al. described the antiproliferative, antimigrative and antiinvasive activities of curcumin on human colon cancer cells HCT116 and LoVo [36]. Curcumin antiproliferative activity has also been proven on human lung cancer cell line A549, human colon cancer cell lines HCT116, human breast cancer cell line MCF7, and human melanoma cell line A375 [37]. Similarly, Pal et al. have demonstrated significant antiproliferative abilities of curcumin on human chronic myeloid leukemia cells KBM-5, human T cell leukemia cells Jurkat, human multiple myeloma cells U266, and human lung cancer cells A549 [38].

In recent years, an increasing number of studies have indicated the importance of resveratrol in cancer chemoprevention [39, 40,41]. The anticancer effect of resveratrol is associated with the induction of apoptosis and/or cell cycle arrest, as well as inhibition of angiogenesis in human ovarian cancer cell lines A2780 and SKOV3 [42], the human malignant melanoma cell line A375SM [43], human colon adenocarcinoma cell line HT-29 [44], glioma cell line U-251 [45], human lung cancer cell line A549 [46], and human acute lymphoblastic leukemia cell line CCRFCEM [47]. Moreover, the inhibitory effect of resveratrol 
on growth in three cell lines, SCC25, CAL27 and FaDu, of human squamous cell carcinoma of the head and neck, as well as its synergistic effect in combination with etoposide have been proven [48]. Therefore, it is worth noting that the resveratrol anticancer effect was based on the increase of cancer cells sensitivity to the effects of currently used chemotherapeutics $[48,49,50]$. Furthermore, another report revealed the cytotoxic effect of resveratrol on the human cholangiocarcinoma cell line SK-ChA-1 [51].

\section{OBJECTIVE}

The aim of the study was to evaluate the influence of different plant extracts and phytochemicals on human NK cell line NK-92 viability, proliferation and integrity of the membranes, as well as cytotoxic activity against human colon cancer cell line LS180. Based on obtained resu, the phytochemical/plant extract with the greatest immunoenhancement properties was selected.

\section{MATERIALS AND METHODS}

Reagents. Unless otherwise indicated, the chemicals used in the study were purchased from Sigma-Aldrich Company LLC (Saint Louis, USA).

Extract and phytochemicals preparation. Curcumin and Resveratrol. Both curcumin and resveratrol were purchased from Sigma-Aldrich Co. LLC. Stock solutions of both phytochemicals $(10 \mathrm{mM})$ were prepared in DMSO and stored at $4{ }^{\circ} \mathrm{C}$. Working solutions were prepared by dissolving the appropriate stock solution in the culture medium just before the experiment.

Extracts of chlorella. Chlorella was purchase from Intenson (Karczew, Poland). Chlorella in the amount of $5 \mathrm{~g}$ was dissolved in $150 \mathrm{ml}$ PBS (phosphate-buffered saline). Extraction was carried out for 24 hours on a rotator at room temperature. The resulting mixture was centrifuged $(4,075$ $\mathrm{x} \mathrm{G}, 10 \mathrm{~min}, 20^{\circ} \mathrm{C}$ ) and the collected supernatant filtered through a microbiological filter. The resulting filtrate was the starting solution, while the precipitate obtained after centrifugation was dried in a thermostat $\left(50^{\circ} \mathrm{C}, 24\right.$ hours), and its mass was used to determine the final concentration of the starting solutions, which was $6.5 \mathrm{mg} / \mathrm{ml}$. Next, the stock solution of the investigated substance was diluted in PBS to prepare stock solutions $(5 \mathrm{mg} / \mathrm{ml})$ and stored at $4{ }^{\circ} \mathrm{C}$. Working solutions were prepared by dissolving the appropriate stock solution in the culture medium just before the experiment.

Goji berries extrac. Goji berries were purchase from Radixbis (Rotmanka, Poland). Goji berries were dried at room temperature and mechanically ground. $25 \mathrm{~g}$ of dried berries were then suspended in $150 \mathrm{ml}$ 96\% ethanol and left on a shaker for seven days, after which the liquid was filtered and evaporated in a vacuum evaporator $\left(60^{\circ} \mathrm{C}\right)$. The residue was again inundated with $150 \mathrm{ml} 96 \%$ ethanol and shaken for another week. Then, the distillate was evaporated, yielding $10.31 \mathrm{~g}$ of extract. The stock solution of goji berries $(10 \mathrm{mg} / \mathrm{ml})$ were prepared in $\mathrm{PBS}$ and stored at $4^{\circ} \mathrm{C}$. Working solutions were prepared by dissolving the stock solution in the culture medium just before the experiment.
Cell lines. Human natural killer cells (NK-92) were obtained from the American Type Culture Collection (ATCC, Manassas, USA). Human colon adenocarcinoma cells (LS180) were obtained from the European Collection of Cell Cultures (ECACC, Centre for Applied Microbiology and Research, Salisbury, UK). NK-92 cells were grown in Alpha Minimum Essential Medium (Sigma) without ribonucleosides and deoxyribonucleosides, and with two $\mathrm{mM}$ L-glutamine and $1.5 \mathrm{mg} / \mathrm{ml}$ sodium bicarbonate supplemented with $0.2 \mathrm{mM}$ inositol, $0.1 \mathrm{mM}$ 2-mercaptoethanol, $0.02 \mathrm{mM}$ folic acid, 200 $\mathrm{U} / \mathrm{ml}$ recombinant IL-2, $12.5 \%$ horse serum and $12.5 \%$ foetal bovine serum (FBS). LS180 cells were grown in a 1:1 mixture of DMEM and nutrient mixture Ham F-12 (Ham's F-12) supplemented with $10 \%$ FBS. All media were supplemented with penicillin $(100 \mathrm{U} / \mathrm{ml})$ and streptomycin $(100 \mu \mathrm{g} / \mathrm{ml})$. Cells were maintained in a humidified atmosphere of $95 \%$ air and $5 \% \mathrm{CO} 2$ at $37^{\circ} \mathrm{C}$.

Impact of plant extracts and phytochemicals on NK92 cells viability and proliferation - MTT assay. NK-92 cells were seeded on 96-well microplates at a density of $1 \times 10^{5}$ cells $/ \mathrm{ml}$ (assessment of proliferation) or $2 \times 10^{5}$ cells $/ \mathrm{ml}$ (viability assessment) and exposed to tested substances for $24 \mathrm{~h}$ in case of viability assessment, and for $48 \mathrm{~h}$ in the case of proliferation assessment. Extracts were used in the following concentrations: $1,5,10,25,50,100,250,500 \mu \mathrm{g} / \mathrm{ml}$. Phytopharmaceuticals were used in following concentrations: $1,2.5,5,10,25,50,75,100 \mu \mathrm{M}$. After 24 or $48 \mathrm{~h}$ of incubation in standard conditions, the cells were investigated by the MTT test. Cells were incubated with MTT solution $(5 \mathrm{mg} / \mathrm{ml}$ in PBS) for $3 \mathrm{~h}$. Then formazan crystals were solubilized overnight in SDS buffer pH $7.4(10 \%$ SDS in $0.01 \mathrm{~N} \mathrm{HCl})$, and the product was quantified spectrophotometrically by measuring the absorbance at $570 \mathrm{~nm}$ wavelength using microplate reader BioTek ELx800 (Highland Park, Winooski, Vermont, USA).

Cytotoxicity of selected substances against NK cells LDH assa. NK-92 cells were seeded on 96-well microplates at a density of $2 \times 10^{5} \mathrm{cells} / \mathrm{ml}$ and exposed to extracts of chlorella and goji berries, as well as curcumin and resveratrol. Extracts were used in following concentrations: 1, 5, 10, 25, $50,100,250$ and $500 \mu \mathrm{g} / \mathrm{ml}$, while phytochemicals were applied in following concentrations: 1, 1.5, 5, 10, 25, 50, 75 and $100 \mu \mathrm{M}$. After $24 \mathrm{~h}$ of NK-92 cells treatment microplates were centrifuged at $300 \times \mathrm{g}, 10 \mathrm{~min}$., at room temperature. The culture supernatants were then collected in new 96well microplates, which were used to perform $\mathrm{LDH}$ assay following the manufacturer's instruction (In vitro Toxicology Assay Kit Lactate Dehydrogenase Based). Absorbance was recorded on a microplate reader BioTek ELx800 at $450 \mathrm{~nm}$ wavelength.

Impact of selected substances on NK-92 cells anticancer activity against LS180 - MTT assay. LS180 cells were seeded on 96 -well microplates at a density of $5 \times 10^{4} \mathrm{cells} / \mathrm{ml}$. The next day, colon cancer cells were exposed to: 1$)$ resveratrol $(0.5,1$, $2.5 \mu \mathrm{M})$ or goji berries extract $(1,2.5,5 \mu \mathrm{g} / \mathrm{ml})$ used alone; 2) NK-92 cells at a density $0.5 \times 10^{4}$ cells $/ \mathrm{ml}, 1 \times 10^{4}$ cells $/ \mathrm{ml}$, $5 \times 10^{4}$ cells $/ \mathrm{ml}, 7.5 \times 10^{4}$ cells $/ \mathrm{ml}$ used alone or together with investigated compounds in above-mentioned concentrations. In the case of co-cultures, the investigated compounds were administered to LS180 cells simultaneously with NK cells. 
After $48 \mathrm{~h}$ of incubation in standard conditions, the culture medium was removed and LS180 cells were washed with PBS. Fresh culture medium was added and the response of LS180 cells to resveratrol or goji berries extract or NK-92 cells activated with tested substances were investigated by MTT test, according to the above-mentioned procedure.

Statistical analysis. The obtained data were developed in the following programmes: Microsoft Excel 2010, GraphPrism 5.0. Results were presented as the mean value \pm standard deviation (SD). Statistical analysis was performed using the one-way ANOVA with Tukey's post-hoc test, and column statistics were used for comparisons. Significance was assumed at $\mathrm{p}<0.05$.

\section{RESULTS}

Impact of plant extracts and phytochemicals on NK cells proliferation. In the first set of experiments, the influence of plant extracts and phytochemicals on NK cell proliferation was examined in NK-92 cells after $48 \mathrm{~h}$ of incubation using the MTT test (Fig. 1).

Chlorella extract in concentrations from $1-50 \mu \mathrm{g} / \mathrm{ml}$ increased NK-92 cell proliferation by $45.0 \%$, on average. The tested extract at a concentration of $100 \mu \mathrm{g} / \mathrm{ml}$, did not affect NK cell divisions. In contrast, chlorella extract at concentrations 250 and $500 \mu \mathrm{g} / \mathrm{ml}$ reduced lymphocyte proliferation by $43.6 \%$ and $92.9 \%$, respectively.

Goji berry extract in concentrations from $1-250 \mu \mathrm{g} / \mathrm{ml}$ increased NK-92 cell proliferation by $61.0 \%$, on average. Tested extract at a concentration of $500 \mu \mathrm{g} / \mathrm{ml}$, did not impact NK cell divisions.

Curcumin at concentrations 1 and $2.5 \mu \mathrm{M}$ did not affect NK cell division. On the contrary, this substance at concentrations ranging from 5-100 $\mu \mathrm{M}$ reduced lymphocyte proliferation in a dose-dependent manner. Curcumin in concentrations from $25 \mu \mathrm{M}$ and above almost completely inhibited divisions of NK cells.

Resveratrol at concentrations $0.5,1,5 \mu \mathrm{M}$ did not affect NK cell division; however, at a concentration of $2.5 \mu \mathrm{M}$ increased NK-92 cell proliferation by $7.6 \%$, whereas, in concentrations from $10-100 \mu \mathrm{M}$ reduced NK lymphocyte proliferation by $67.1 \%$, on average.

Impact of plant extracts and phytochemicals on NK cells viability. In the second set of experiments, the influence of plant extracts and phytochemicals on NK cell viability was examined in NK-92 cells after $24 \mathrm{~h}$ of incubation using both LDH and MTT assays (Fig. 2).

Chlorella extract in concentrations from $1-100 \mu \mathrm{g} / \mathrm{ml}$, did not impact NK cell viability, but at concentrations 250
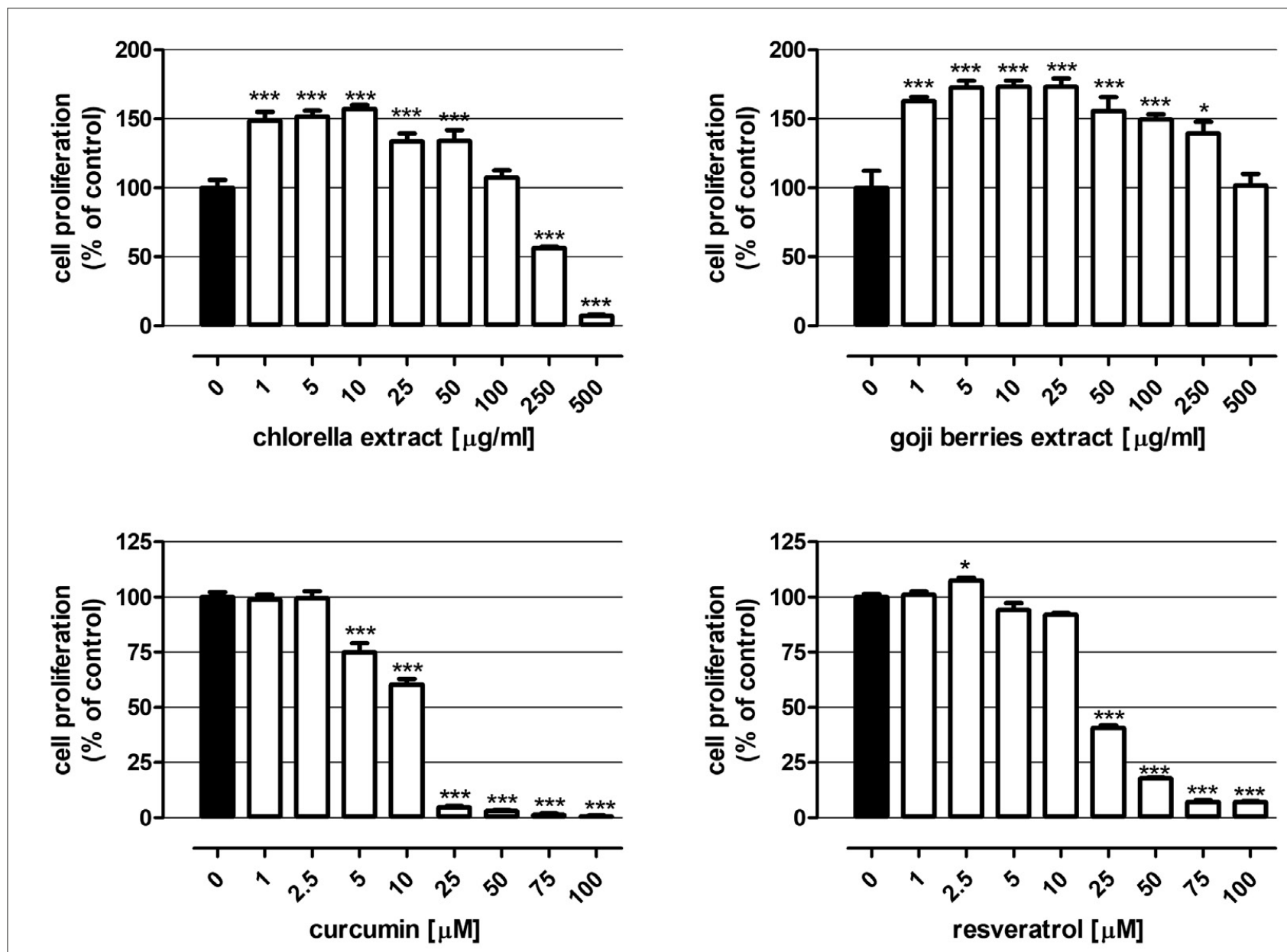

Figure 1. The influence of selected phytochemicals or plant extracts on NK-92 cell proliferation. Cells were exposed for $48 \mathrm{~h}$ to the culture medium alone (control), or the extracts of chlorella or goji berries in the following concentrations: $1 ; 5 ; 10 ; 25 ; 50 ; 100 ; 250 ; 500 \mu \mathrm{g} / \mathrm{ml}$, as well as resveratrol or curcumin in the following concentrations: $1,2.5,5,10,25,50,75$ and $100 \mu \mathrm{M}$. Cell proliferation was determined by examination of metabolic activity using the MTT assay. Results are presented as mean \pm SD. ${ }^{*} \mathrm{p}$ $<0.05 ;{ }^{* * *} \mathrm{p}<0.001$ vs. control, one-way ANOVA test; post-hoc test: Tukey. 
A
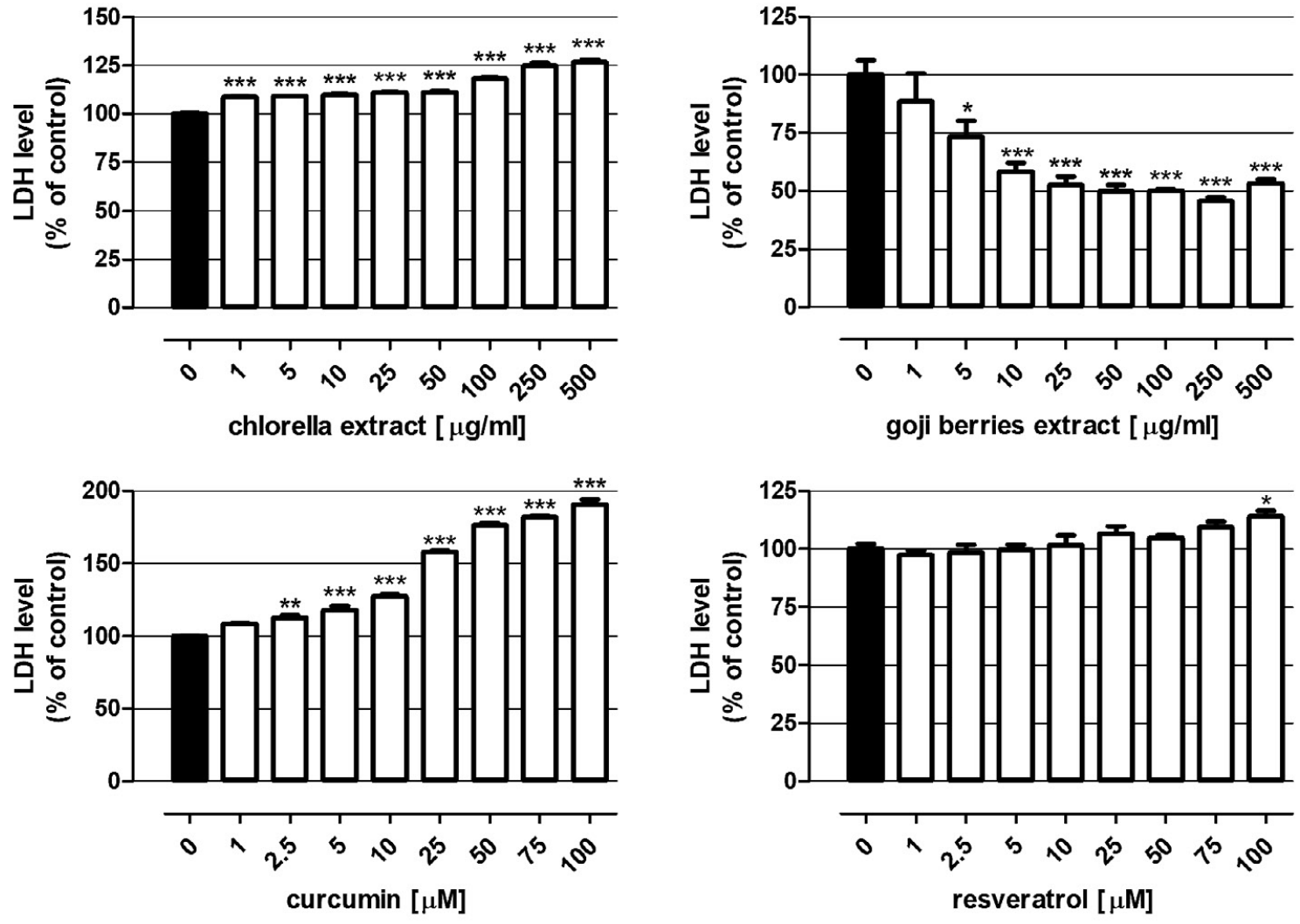

B
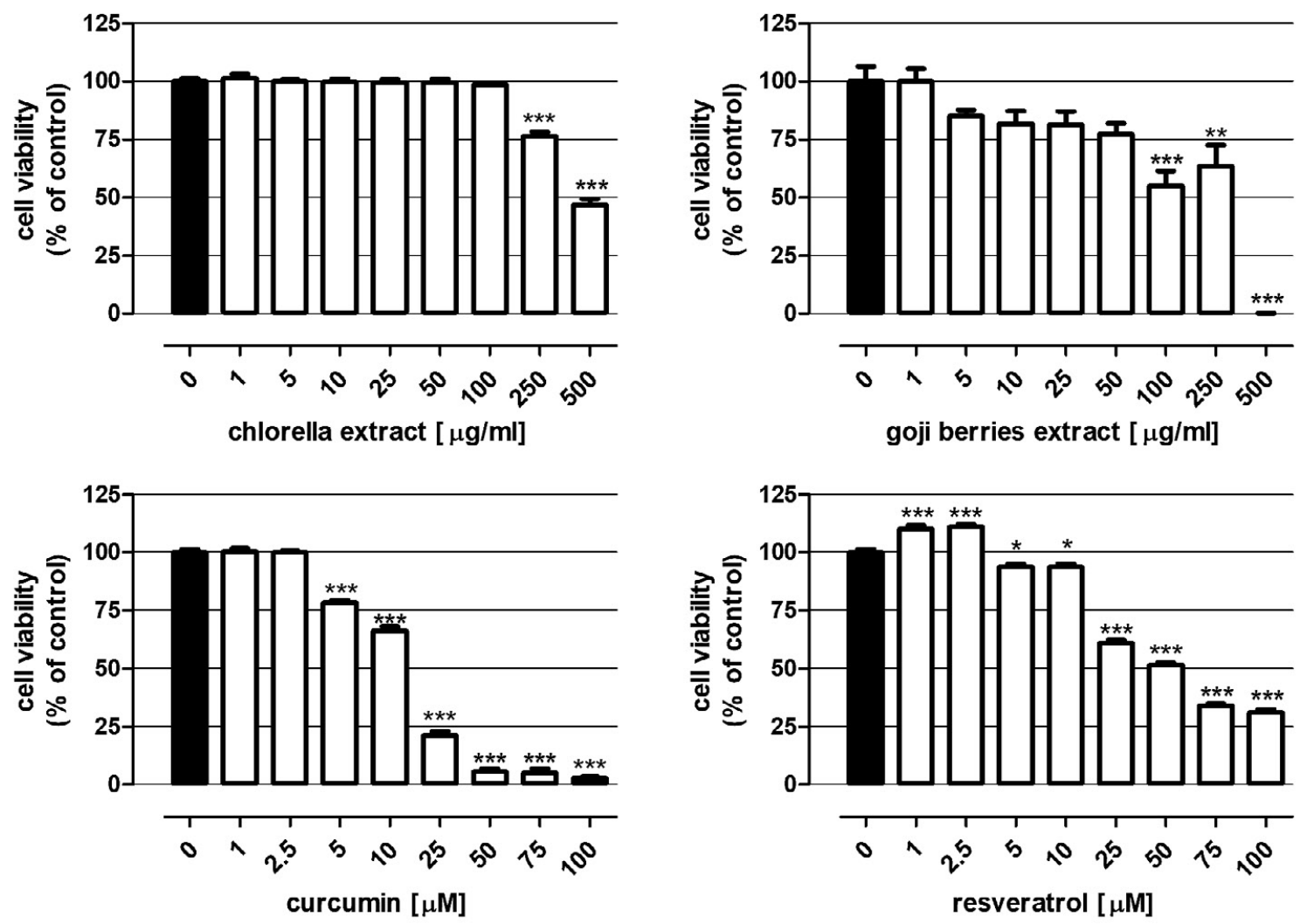

Figure 2. The influence of selected phytochemicals or plant extracts on NK-92 cell viability. Cells were exposed for $24 \mathrm{~h}$ to the culture medium alone (control), or the extracts of chlorella or goji berries in the following concentrations: $1 ; 5 ; 10 ; 25 ; 50 ; 100 ; 250 ; 500 \mu \mathrm{g} / \mathrm{ml}$, as well as resveratrol or curcumin in the following concentrations: $1,2.5,5,10,25,50,75,100 \mu \mathrm{M}$. Cell viability was determined by examination of both cell membrane integrity using the LDH assay (A), and metabolic activity using the MTT assay (B). Results are presented as mean \pm SD. ${ }^{*} p<0.05 ;{ }^{* *} p<0.01 ;{ }^{* * *} p<0.001$ vs. control, one-way ANOVA test; post-hoc test: Tukey. 
and $500 \mu \mathrm{g} / \mathrm{ml}$ reduced lymphocyte viability by $38.3 \%$, on average. Nevertheless, the LDH test revealed cytotoxicity of chlorella extract in the whole range of tested concentrations.

Goji berry extract in concentrations from $1 \mu \mathrm{g} / \mathrm{ml}-50 \mu \mathrm{g} / \mathrm{ml}$ did not impact NK cells viability. On the contrary, the tested extract at concentrations 100,250 and $500 \mu \mathrm{g} / \mathrm{ml}$ reduced NK cells viability by $45 \%, 36.5 \%$ and $99.9 \%$, respectively. Goji berry extract in concentrations from 5-500 $\mu \mathrm{g} / \mathrm{ml}$ inhibited the release of $\mathrm{LDH}$, maintaining its concentration on average at $54.7 \%$ of control.

Curcumin at concentrations ranging from $2.5-100 \mu \mathrm{M}$ increased LDH release by NK cells, and the observed effect was dose-dependent. $\mathrm{LDH}$ concentration reached the level of $190.7 \%$ of control at the highest tested curcumin concentration. Simultaneously, the investigated compound in concentrations from 5-100 $\mu \mathrm{M}$ decreased NK-92 cell viability. The most significant reduction of cell number (95.5\% decrease, on average) was noted at concentrations 50,75 and $100 \mu \mathrm{M}$.

Resveratrol in concentrations from 1-75 $\mu \mathrm{M}$ did not affect the LDH level, while at a concentration of $100 \mu \mathrm{M}$ increased enzyme release by $14.1 \%$. The tested substance at concentrations 1 and $2.5 \mu \mathrm{g} / \mathrm{ml}$ increased lymphocyte viability by $10.2 \%$ and $11.1 \%$, respectively. Nevertheless, resveratrol at a concentration of $5 \mu \mathrm{M}$ and higher decreased NK-92 cell viability in a dose-dependent manner. The strongest $68.9 \%$ reduction in viability was observed at a concentration of $100 \mu \mathrm{g} / \mathrm{ml}$.
Influence of resveratrol and goji berries extract on NK cells anticancer activity against cancer cells. In order to examine the immunomodulatory properties of resveratrol and goji berries extract, their impact on the anticancer properties of NK cells was tested against human colon cancer cell line LS180, using the MTT test. Studies were performed after 48 $\mathrm{h}$ of LS180 cells incubation with NK-92 cells in the presence or absence of the substances (Fig. 3).

Resveratrol at all examined concentrations (0.5, 1 and 2.5 $\mu \mathrm{M}$ ) did not impact colon cancer cell proliferation (Fig. 3A). On the contrary, NK-92 cells used alone effectively eliminated LS180 cells, and the observed effect was dependent on NK cell number. The strongest anticancer effect (elimination of $94.0 \%$ of cancer cells, on average) was noted with a ratio of LS180 to NK cells of 2:3. On the contrary, NK-92 cells administration in an amount 10-times lower than LS180 cells number, caused a reduction of colon cancer cell viability by 9.4\%. LS180 cells exposure simultaneously to both NK-92 cells and resveratrol revealed that the tested compound did not impact the anticancer activity of NK cells. A significant decrease was observed in the number of colon cancer cells treated with NK cells, and resveratrol was dependent only on the number of effector cells. The most significant colon cancer elimination was noted when LS180 cells were incubated with NK cells in the ratio 2:3. The viability of LS180 cells, incubated with NK-92 cells in combination with resveratrol at concentrations $0.5,1$ and $2.5 \mu \mathrm{M}$, was reduced by $94.9 \%$, on average, but a similar range of changes was observed without the tested compounds.

\section{A}

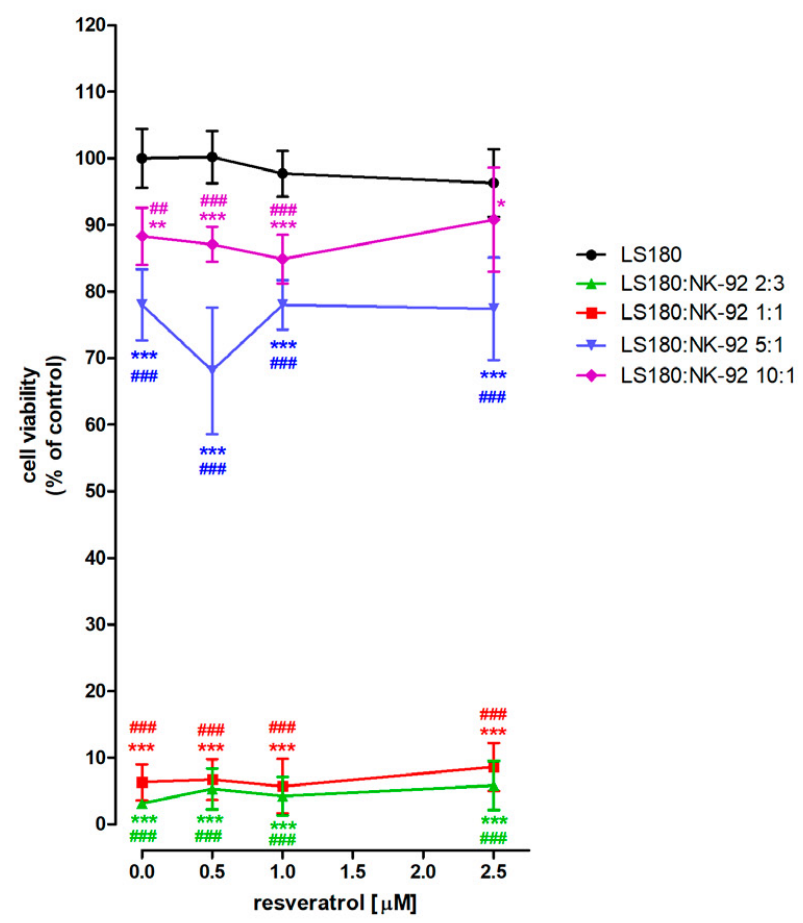

B

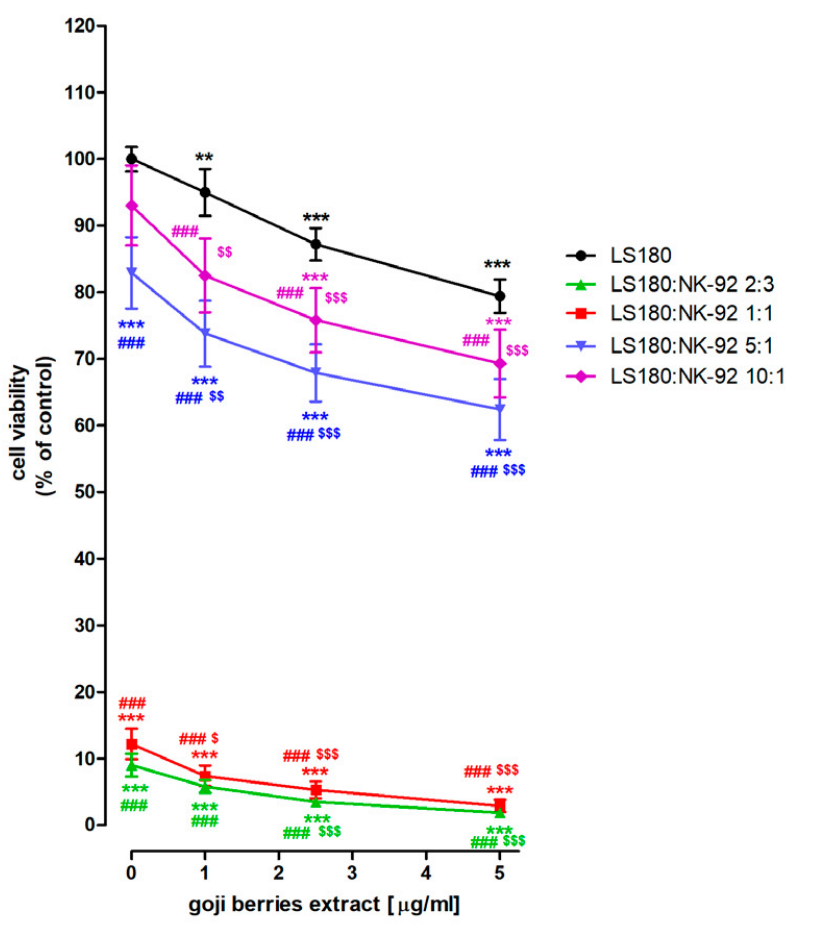

Figure 3. The influence of resveratrol or goji berries extract on NK-92 cells cytotoxicity against human colon cancer cell line LS180. LS180 cells were exposed $48 \mathrm{~h}$ to the culture medium alone (control), or resveratrol at concentrations: $0.5,1,2.5 \mu \mathrm{M}$, or goji berries extract at concentrations: $1,2.5,5 \mu \mathrm{g} / \mathrm{ml}$, or NK-92 cells with or without investigated compounds at mentioned concentrations. NK-92 cells were used in the following proportions against cancer cells: 3:2, 1:1, 1:5, 1:10, where 1 correspond to $5 \times 104$ cells $/ \mathrm{ml}$. Cell viability was determined by the examination of metabolic activity by MTT assay. Results are presented as mean \pm SD. Statistically significant differences compared to the control at $\mathrm{p}<0.05\left(^{*}\right) ; \mathrm{p}<0.01\left(^{* *}\right) ; \mathrm{p}<0.001\left(^{* * *}\right)$. Statistically significant differences between LS180 cells treated with NK-92 cells activated by tested compounds vs. LS180 cells treated with investigated compounds (the comparison was made in the corresponding tested compounds concentrations) at $p$ $<0.01$ (\#\#); $\mathrm{p}<0.001$ (\#\#\#). Statistically significant differences between LS180 cells treated with NK-92 cells activated by tested compounds vs. LS180 cells treated with NK-92 cells used alone (the comparison was made in corresponding concentration of NK-92 cells) at $\mathrm{p}<0.01$ ( $\$$ ); $<<0.001$ (\$\$). One-way ANOVA test; post-hoc test: Tukey. 
The second set of experiments (dedicated to goji berries extract) confirmed that NK-92 cells used alone effectively eliminated LS180 cells themselves, and the effect observed was dependent on the number of NK cells (Fig. 3B). The strongest anticancer effect (elimination of $91 \%$ cancer cells) was noted with a ratio of LS180 to NK cells of $1: 1$. On the contrary, NK-92 cells administration in an amount 10-times lower than LS180 cells number, did not impact colon cancer cells proliferation, while the amount 5 -times lower caused a reduction of colon cancer cells viability by $17.1 \%$. Goji berries extract at all tested concentrations (1, 2.5, $5 \mu \mathrm{g}$ / $\mathrm{ml}$ ) reduced colon cancer cells proliferation by $5 \%, 12.8 \%$ and $20.6 \%$, respectively. Furthermore, the tested extract significantly increased the anticancer activity of NK cells against colon cancer cells, and the observed effect depended on both the extract concentration and the number of effector cells. The strongest anticancer effect was noted with a ratio of LS180 to NK cells of 2:3. NK cells used alone eliminated $91.0 \%$ of cancer cells, while the viability of LS180 cells after incubation with both NK-92 cells and goji berries extract at concentrations 2.5 and $5 \mu \mathrm{g} / \mathrm{ml}$, was significantly reduced by $96.5 \%$ and $98.1 \%$, respectively. Similarly, NK cells used in a 1:1 ratio to cancer cells reduced their number by $87.8 \%$, while applied together with tested extract eliminated over $94.8 \%$ of LS180 cells, and enhancement of NK cell, the anticancer effect was noted in all investigated concentrations of the tested extract. As mentioned previously, the weakest elimination of colon cancer was observed in the experiment where the ratio of target cells to effector cells was 10:1, reduction of LS180 cells number in the presence of NK cells alone was not statistically significant. Nevertheless, the viability of LS180 cells in response to incubation with NK-92 cells at a density $0.5 \times 10^{4}$ cells $/ \mathrm{ml}$ administered togethe with goji berry extract in concentrations $1,2.5$ and $5 \mu \mathrm{g} / \mathrm{ml}$, decreased by $17.5 \%$, $24.2 \%$ and $10.7 \%$ respectively.

\section{DISCUSSION}

The aim of the study was assessment of the immunomodulatory properties of selected plant extracts and phytochemicals in the NK cell model. In order to reach this goal, the effect of chlorella extract, goji berries extract, curcumin, and resveratrol on the proliferation, viability, and membrane integrity of human NK cell line NK-92, was examined. The influence of goji berries and resveratrol on anticancer activity of NK-92 cells against human colon cancer cell line LS180 was shown.

MTT test performed after 48 hours of NK cells exposure to chlorella extract, goji berries extract, curcumin and resveratrol, revealed that both tested extracts in a wide range of concentrations significantly increased NK-92 cell proliferation. On the contrary, curcumin and resveratrol in low concentrations did not affect NK cell proliferation; however, high doses decreased their metabolic activity in a dose-dependent manner. The same test conducted after 24 hours of NK cells treatment with the investigated compounds showed that chlorella extract and goji berries extract, in a wide range of concentrations, as well as curcumin in low doses, did not impact the viability of NK-92 cells. Resveratrol in low concentrations significantly increased NK cells metabolic activity. On the contrary, both curcumin and resveratrol with increasing concentration, decreased lymphocyte viability.
Examination of the selected phytochemicals and plant extracts cytotoxicity against NK cells demonstrated a significant increase of LDH level in NK-92 cells after 24 hours of exposure to chlorella extract, and curcumin in the whole range of tested concentrations. On the contrary, goji berries extract significantly decreased LDH level, while resveratrol did not affect the integrity of membranes of NK cells.

Based on the above-mentioned results, especially cytotoxicity examination for further studies, resveratrol and goji berries extract were selected, to investigate the impact on NK cells ability to recognize and eliminate cancer cells against human colon cancer cell line LS180. Furthermore, the direct anticancer effect of the selected compounds was also examined.

Despite the beneficial impact of resveratrol on NK-92 cell viability and proliferation, the performed studies did not show chemopreventive properties of this compound, which was unable to increase NK cells cytotoxicity against LS180 cells. There are relatively many studies describing the positive effect of resveratrol on NK cell activity. Lu et al proved an increase in the cytotoxic activity of NK-92 cells treated with resveratrol by increasing the activity of JNK and ERK-1/2 MAP kinases, as well as stimulation of the expression of perforin and NKG2D [52]. In contrast to the presented study, other studies have confirmed the increase in the NK cells cytotoxicity against the following human cancer cell lines: chronic myelogenous leukemia (CML) K-562, hepatocellular carcinoma HepG2 and lung carcinoma A549 [52]. Similarly, Luis Espinoza et al. proved the susceptibility of different leukemic cell lines (MOLT-4, THP1, KG1, Jurkat, HL60, OUN1, and TF1) to NK cells (obtained from PBMCs) cytotoxicity, which was associated with resveratrol induced increase of expression of NKG2D-L molecule on leukemic cells, which is a ligand for NK cells receptor NKG2D [53]. They also reported beneficial effects of resveratrol on NK cells in healthy people by increasing the expression of the mentioned NKG2D receptor. Nevertheless, in accordance with the presented results, they also revealed that higher concentrations of resveratrol reduced the viability of NK cells [53]. Li et al. have shown higher cytotoxicity of NK cell line YAC-1 treated with resveratrol against mouse lymphocytic leukemia cells L1210 [54]. Surprisingly, resveratrol used alone was not able to eliminate colon cancer LS180 cells. The recorded lack of direct anticancer properties is in contrast to other studies. Segun et al. demonstrated the antiproliferative activity of three resveratrol derivatives against a wide range of human cancer cell lines: breast adenocarcinoma MCF7, lung carcinoma A549, prostate adenocarcinoma PC-3, and hepatocellular carcinoma HepG2. In addition, the mentioned compounds showed low toxicity to the normal human prostate cell line PNT2 [55]. Research conducted by Heiduschka et al. on three head and neck squamous cell carcinoma (HNSCC) cell lines: SCC25, CAL27, and FaDu, has shown growth inhibition as well as cell death induction in all tested lines in response to resveratrol [48]. ZielińskaPrzyjemska et al. demonstrated the antiproliferative abilities of resveratrol in the human glioblastoma cell line T98G, and suggested that the tested compound should be used as an adjuvant in glioblastoma therapy [56].

On the contrar, goji berries extract significantly decreased the viability of LS180 cells as well as clearly strengthened NK92 cells killing activity towards colon cancer cells. It needs to be highlighted that the identified immunoenhancement 
abilities of goji berries extract were dependent on the tested compound dose, as well as the number of lymphocytes used to fight cancer cells. There is little research in the literature on the effect of goji berries on NK cells. Only Huyan et al. studied L. barbarum polysaccharides (LBP) and proved that they enhance the cytotoxicity of NK cells isolated from PBMCs against the K-562 lineage through greater INF- $\gamma$ and perforin secretion, and higher NKp30 receptor expression [57]. Additionally, the beneficial impact of L. barbarum polysaccharides (LBP) has also been reported by Cao et al. who revealed significant regression of diseases in patients with malignant melanoma, renal cell carcinoma, colorectal carcinoma, lung cancer, nasopharyngeal carcinoma and, malignant hydrothorax, as a result of enhancement of NK and LAK activity by LBP [58].

The observed direct anticancer effect of goji berries extract is supported by many other reports. Georgiev et al. proved that the L. barbarum pectin-free fraction selectively inhibited the growth of breast cancer cell lines MCF-7 and MD-MB-231 [32]. Wawruszak et al. demonstrated the anticancer effect of ethanol extract of goji berries (EEGB) on a human breast cancer cell line (T47D) [31]. Furthermore, the antiproliferative effect of goji berries was also reported in human colon cancer cell line Caco-2 [59, 60], human hepatoma cell line QGY7703 [61], and human gastric cancer cell lines MGC-803 and SGC-7901 [62].

\section{CONCLUSIONS}

Despite the fact that the presented study was performed only on NK cell lines, their importance is increased by the fact that the research was conducted on human NK-92 cell line with proven therapeutic efficacy in clinical studies $[3,63]$. Thus, a beneficial effect was discovered of goji berries extract on NK-92 cells viability, proliferation, and above all, elimination of colon cancer cells, which brings hope for future use of goji berries in cancer immunotherapy. Furthermore, the discovered direct anticancer abilities of goji berries extract also increases the chances for its effective use in colon cancer immunotherapy. Nevertheless, further studies, including isolation and description of bioactive compounds presented in the tested extract, as well as an understanding of the molecular mechanism of their interaction with NK cells, are required.

\section{REFERENCES}

1. Bishayee A, Sethi G. Bioactive natural products in cancer prevention and therapy: Progress and promise. Semin Cancer Biol. 2016; 40-41: 1-3. https://doi.org/10.1016/j.semcancer.2016.08.006

2. Rejhová A, OpattováA, Čumová A, Slíva D, Vodička P. Natural compounds and combination therapy in colorectal cancer treatment. Eur J Med Chem. 2018; 144: 582-594. https://doi.org/10.1016/j. ejmech.2017.12.039

3. Kwaśnik P, Lemieszek MK, Rzeski W. Możliwości wykorzystania komórek NK w immunoterapii nowotworów. Med Og Nauk Zdr. 2020; 26(1): 8-16. https://doi.org/10.26444/monz/116591

4. Kim NH, Kim KY, Jeong HJ, Kim HM, Hong SH, Um JY. Effects of hydrolyzed Chlorella vulgaris by malted barley on the immunomodulatory response in ICR mice and in Molt- 4 cells. J Sci Food Agric. 2010; 90(9): 1551-1556. https://doi.org/10.1002/jsfa.3989

5. Cheng D1, Wan Z, Zhang X, Li J, Li H, Wang C. Dietary Chlorella vulgaris ameliorates altered immunomodulatory functions in cyclophosphamide-induced immunosuppressive mice. Nutrients. 2017; 9(7): E708. https://doi.org/ 10.3390/nu9070708
6. Ishiguro S, Robben N, Burghart R, Cote P, Greenway S, Thakkar R, et al. Cell wall membrane fraction of Chlorella sorokiniana enhances host antitumor immunity and inhibits colon carcinoma growth in mice. Integr Cancer Ther. 2020; 19: 1534735419900555. https://doi. org/10.1177/1534735419900555

7. Qi J, Kim SM. Characterization and immunomodulatory activities of polysaccharides extracted from green alga Chlorella ellipsoidea. Int J Biol Macromol. 2017; 95: 106-114. https://doi.org/ 10.1016/j. ijbiomac.2016.11.039

8. Qi J, Kim SM. Effects of the molecular weight and protein and sulfate content of Chlorella ellipsoidea polysaccharides on their immunomodulatory activity. Int J Biol Macromol. 2018; 107(Pt A): 70-77. https://doi.org/ 10.1016/j.ijbiomac.2017.08.144

9. Morris HJ, Carrillo O, Almarales A, Bermudez RC, Lebequee Y, Fontaine $\mathrm{R}$, et al. Immunostimulant activity of an enzymatic protein hydrolysate from green microalga Chlorella vulgaris on undernourished mice. Enzyme Microb Tech. 2007; 40: 456-460. https://doi.org/10.1016/j. enzmictec.2006.07.021

10. Povolo C, Foschini A, Ribaudo G. Optimization of the extraction of bioactive molecules from Lycium barbarum fruits and evaluation of the antioxidant activity: a combined study. Nat Prod Res. 2019; 33(18): 2694-2698. https://doi.org/ 10.1080/14786419.2018.1460835

11. Lin FY, Lai YK, Yu HC, Chen NY, Chang CY, Lo HC, et al. Effects of Lycium barbarum extract on production and immunomodulatory activity of the extracellular polysaccharopeptides from submerged fermentation culture of Coriolus versicolor. Food Chem. 2008; 110(2): 446-453. https://doi.org/10.1016/j.foodchem.2008.02.023

12. Zhu PF, Zhao YL, Dai Z, Qin XJ, Yuan HL, Jin Q, et al. Phenolic amides with immunomodulatory activity from the nonpolysaccharide fraction of Lycium barbarum fruits. J Agric Food Chem. 2020; 68(10): 3079-3087. https://doi.org/ 10.1021/acs.jafc.9b07499

13. Gong Y, Wu J, Li ST. Immuno-enhancement effects of Lycium ruthenicum Murr. polysaccharide on cyclophosphamide-induced immunosuppression in mice. Int J Clin Exp Med. 2015; 8(11): 20631-20637.

14. Shakeri F, Boskabady MH. Anti-inflammatory, antioxidant, and immunomodulatory effects of curcumin in ovalbumin-sensitized rat. Biofactors. 2017; 43(4): 567-576. https://doi.org/10.1002/biof.1364

15. Srivastava RM, Singh S, Dubey SK, Misra K, Khar A. Immunomodulatory and therapeutic activity of curcumin. Int Immunopharmacol. 2011; 11(3): 331-341. https://doi.org/10.1016/j.intimp.2010.08.014

16. Gao X, Kuo J, Jiang H, Deeb D, Liu Y, Divine G, et al. Immunomodulatory activity of curcumin: suppression of lymphocyte proliferation, development of cell-mediated cytotoxicity, and cytokine production in vitro. Biochem Pharmacol. 2004; 68(1): 51-61. https://doi.org/10.1016/j. bcp.2004.03.015

17. Shahid H, Shahzad M, Shabbir A, Saghir G. Immunomodulatory and anti-inflammatory potential of curcumin for the treatment of allergic asthma: effects on expression levels of pro-inflammatory cytokines and aquaporins. Inflammation. 2019; 42(6): 2037-2047. https://doi. org/ 10.1007/s10753-019-01066-2

18. Mohammadi A, Blesso CN, Barreto GE, Banach M, Majeed M, Sahebkar A. Macrophage plasticity, polarization and function in response to curcumin, a diet-derived polyphenol, as an immunomodulatory agent. J Nutr Biochem. 2019; 66: 1-16. https://doi.org/10.1016/j. jnutbio.2018.12.005

19. Wang S, Li H, Zhang M, Yue LT, Wang CC, Zhang P, et al. Curcumin ameliorates experimental autoimmune myasthenia gravis by diverse immune cells. Neurosci Lett. 2016; 626: 25-34. https://doi.org/10.1016/j. neulet.2016.05.020

20. Fuggetta M, Mattivi F. The immunomodulating activities of resveratrol glucosides in humans. Recent Pat Food Nutr Agric. 2011; 3(2): 81-90.

21. de Sá Coutinho D, Pacheco MT, Frozza RL, Bernardi A. AntiInflammatory Effects of Resveratrol: Mechanistic Insights. Int J Mol Sci. 2018; 19(6): E1812. https://doi.org/ 10.3390/ijms19061812

22. Euba B, López-López N, Rodríguez-Arce I, Fernández-Calvet A, Barberán M, Caturla N, et al. Resveratrol therapeutics combines both antimicrobial and immunomodulatory properties against respiratory infection by nontypeable Haemophilus influenzae. Sci Rep. 2017; 7(1): 12860. https://doi.org/ 10.1038/s41598-017-13034-7

23. Cui Q, Fu Q, Zhao X, Song X, Yu J, Yang Y, et al. Protective effects and immunomodulation on piglets infected with rotavirus following resveratrol supplementation. PLoS One. 2018; 13(2): e0192692. https:// doi.org/10.1371/journal.pone.0192692

24. Rencber SF, Ozbek SK, Eraldemır C, Sezer Z, Kum T, Ceylan S, et al. Effect of resveratrol and metformin on ovarian reserve and ultrastructure in PCOS: an experimental study. J Ovarian Res. 2018; 11(1): 55. https://doi.org/ 10.1186/s13048-018-0427-7 
25. Kyadari M, Fatma T, Azad R, Velpandian T. Evaluation of antiangiogenic and antiproliferative potential of the organic extract of green algae Chlorella pyrenoidosa. Indian J Pharmacol. 2013; 45(6): 569-574. https://doi.org/ 10.4103/0253-7613.121366

26. Karakaş CY, Tekarslan Şahin H, İnan B, Özçimen D, Erginer YÖ. In vitro cytotoxic activity of microalgal extracts loaded nano-micro particles produced via electrospraying and microemulsion methods. Biotechnol Prog. 2019; 35(6): e2876. https://doi.org/ 10.1002/btpr.2876

27. Zhang J, Liu L, Ren Y, Chen F. Characterization of exopolysaccharides produced by microalgae with antitumor activity on human colon cancer cells. Int J Biol Macromol. 2019; 128: 761-767. https://doi.org/10.1016/j. ijbiomac.2019.02.009

28. Kubatka P, Kapinová A, Kružliak P, Kello M, Výbohová D, Kajo K, et al. Antineoplastic effects of Chlorella pyrenoidosa in the breast cancer model. Nutrition. 2015; 31(4): 560-569. https://doi.org/ 10.1016/j. nut.2014.08.010

29. Gong G, Liu Q, Deng Y, Dang T, Dai W, Liu T, et al. Arabinogalactan derived from Lycium barbarum fruit inhibits cancer cell growth via cell cycle arrest and apoptosis. Int J Biol Macromol. 2020; 149: 639-650. https://doi.org/ 10.1016/j.ijbiomac.2020.01.251

30. Mao F, Xiao B, Jiang Z, Zhao J, Huang X, Guo J. Anticancer effect of Lycium barbarum polysaccharides on colon cancer cells involves G0/ G1 phase arrest. Med Oncol. 2011; 28(1): 121-126. https://doi.org/ 10.1007/s12032-009-9415-5

31. Wawruszak A, Czerwonka A, Okła K, Rzeski W. Anticancer effect of ethanol Lycium barbarum (Goji berry) extract on human breast cancer T47D cell line. Nat Prod Res. 2016; 30(17): 1993-1996.

32. Georgiev KD, Slavov IJ, Iliev IA. Antioxidant activity and antiproliferative effects of Lycium barbarum's (goji berry) fractions on breast cancer cell lines. Folia Med (Plovdiv). 2019; 61(1): 104-112. https://doi.org/ 10.2478/folmed-2018-0053

33. Chen S, Liang L, Wang Y, Diao J, Zhao C, Chen G, et al. Synergistic immunotherapeutic effects of Lycium barbarum polysaccharide and interferon- $a 2 b$ on the murine Renca renal cell carcinoma cell line in vitro and in vivo. Mol Med Rep. 2015; 12(5): 6727-6737. https://doi. org/10.3892/mmr.2015.4230

34. Mortezaee K, Salehi E, Mirtavoos-Mahyari H, Motevaseli E, Najafi M, Farhood B, et al. Mechanisms of apoptosis modulation by curcumin: Implications for cancer therapy. J Cell Physiol. 2019; 234(8): 1253712550. https://doi.org/ 10.1002/jcp. 28122

35. Yue GG, Chan BC, Hon PM, Lee MY, Fung KP, Leung PC. Evaluation of in vitro anti-proliferative and immunomodulatory activities of compounds isolated from Curcuma longa. Food Chem Toxicol. 2010; 48(8-9): 2011-2020. https://doi.org/ 10.1016/j.fct.2010.04.039

36. Calibasi-Kocal G, Pakdemirli A, Bayrak S, Ozupek NM, Sever T, Basbinar Y, et al. Curcumin effects on cell proliferation, angiogenesis and metastasis in colorectal cancer. J BUON. 2019; 24(4): 1482-1487.

37. Srivastava NS, Srivastava RAK. Curcumin and quercetin synergistically inhibit cancer cell proliferation in multiple cancer cells and modulate Wnt/ $\beta$-catenin signaling and apoptotic pathways in A375 cells. Phytomedicine. 2019; 52: 117-128. https://doi.org/10.1016/j. phymed.2018.09.224

38. Pal A, Sung B, Bhanu Prasad BA, Schuber PT Jr, Prasad S, Aggarwal $\mathrm{BB}$, et al. Curcumin glucuronides: assessing the proliferative activity against human cell lines. Bioorg Med Chem. 2014; 22(1): 435-439. https://doi.org/ 10.1016/j.bmc.2013.11.006

39. Breuss JM, Atanasov AG, Uhrin P. Resveratrol and its effects on the vascular system. Int J Mol Sci. 2019; 20(7): 1523. https://doi.org/10.3390/ ijms20071523

40. Pezzuto JM. Resveratrol: Twenty Years of Growth, Development and Controversy. Biomol Ther (Seoul). 2019; 27(1): 1-14. https://doi. org/10.4062/biomolther.2018.176

41. Carter LG, D'Orazio JA, Pearson KJ. Resveratrol and cancer: focus on in vivo evidence. Endocrine-Related Cancer 2014; 21: 209-225. https:// doi.org/10.1530/ERC-13-0171

42. Kim TH, Park JH, Woo JS. Resveratrol induces cell death through ROS-dependent downregulation of Notch1/PTEN/Akt signaling in ovarian cancer cells. Mol Med Rep. 2019; 19(4): 3353-3360. https://doi. org/10.3892/mmr.2019.9962

43. Heo JR, Kim SM, Hwang KA, Kang JH, Choi KC. Resveratrol induced reactive oxygen species and endoplasmic reticulum stress-mediated apoptosis, and cell cycle arrest in the A375SM malignant melanoma cell line. Int J Mol Med. 2018; 42(3): 1427-1435. https://doi.org/10.3892/ ijmm.2018.3732

44. Pouyafar A, Rezabakhsh A, Rahbarghazi R, Heydarabad MZ, Shokrollahi E, Sokullu E, et al. Treatment of cancer stem cells from human colon adenocarcinoma cell line HT-29 with resveratrol and sulindac induced mesenchymal-endothelial transition rate. Cell Tissue Res. 2019; 376(3): 377-388. https://doi.org/10.1007/s00441-019-02998-9

45. Liu L, Zhang Y, Zhu K, Song L, Tao M, Huang P, et al. Resveratrol inhibits glioma cell growth via targeting LRIG1. J BUON. 2018; 23(2): 403-409.

46. Yuan L, Zhang Y, Xia J, Liu B, Zhang Q, Liu J, et al. Resveratrol induces cell cycle arrest via a p53-independent pathway in A549 cells. Mol Med Rep. 2015; 11(4): 2459-2464. https://doi.org/10.3892/mmr.2014.3100

47. Zadi Heydarabad M, Nikasa M, Vatanmakanian M, Azimi A, Farshdousti Hagh M. Regulatory effect of resveratrol and prednisolone on MDR1 gene expression in acute lymphoblastic leukemia cell line (CCRF-CEM): An epigenetic perspective. J Cell Biochem. 2018; 119(6): 4890-4896. https://doi.org/10.1002/jcb.26709

48. Heiduschka G, Bigenzahn J, Brunner M, Thurnher D. Resveratrol synergistically enhances the effect of etoposide in HNSCC cell lines. Acta Otolaryngol. 2014; 134(10): 1071-1078. https://doi.org/10.3109/0 0016489.2014 .888592

49. Walle T. Bioavailability of resveratrol. Annals of the New York Academy of Sciences. Ann N Y Acad Sci. 2011; 1215: 9-15. doi: 10.1111/j.17496632.2010.05842.x

50. Koushki M, Amiri-Dashatan N, Ahmadi N, Abbaszadeh HA, RezaeiTavirani M. Resveratrol: A miraculous natural compound for diseases treatment. Food Sci Nutr. 2018; 6(8): 2473-2490. https://doi.org/10.1002/ fsn 3.855

51. Roncoroni L, Elli L, Dolfini E, Erba E, Dogliotti E, Terrani C, et al. Resveratrol inhibits cell growth in a human cholangiocarcinoma cell line. Liver Int. 2008; 28(10): 1426-1436. https://doi.org/ 10.1111/j.14783231.2008.01749

52. Lu CC, Chen JK. Resveratrol enhances perforin expression and NK cell cytotoxicity through NKG2D-dependent pathways. J Cell Physiol. 2010; 223(2): 343-351. https://doi.org/10.1002/jcp.22043

53. Espinoza JL, Takami A, Trung LQ, et al. Ataxia-telangiectasia mutated kinase-mediated upregulation of NKG2D ligands on leukemia cells by resveratrol results in enhanced natural killer cell susceptibility. Cancer Sci. 2013; 104(6): 657-662. https://doi.org/10.1111/cas.12141

54. Li T, Fan GX, Wang W, et al. Resveratrol induces apoptosis, influences IL-6 and exerts immunomodulatory effect on mouse lymphocytic leukemia both in vitro and in vivo. Int Immunopharmacol. 2007; 7(9): 1221-1231. https://doi.org/10.1016/j.intimp.2007.05.008

55. Segun PA, Ogbole OO, Ismail FMD, Nahar L, Evans AR, Ajaiyeoba EO, et al. Resveratrol derivatives from Commiphora africana (A. Rich.) Endl. display cytotoxicity and selectivity against several human cancer cell lines. Phytother Res. 2019; 33(1): 159-166. https://doi.org/10.1002/ ptr.6209

56. Zielińska-Przyjemska M, Kaczmarek M, Krajka-Kuźniak V, Łuczak M, Baer-Dubowska W. The effect of resveratrol, its naturally occurring derivatives and tannic acid on the induction of cell cycle arrest and apoptosis in rat C6 and human T98G glioma cell lines. Toxicol In Vitro. 2017; 43: 69-75. https://doi.org/10.1016/j.tiv.2017.06.004

57. Cao GW, Yang WG, Du P. Observation of the effects of LAK/IL-2 therapy combining with Lycium barbarum polysaccharides in the treatment of 75 cancer patients. Zhonghua Zhong Liu Za Zhi. 1994; 16(6): 428-431.

58. Huyan T, Li Q, Yang H, et al. Protective effect of polysaccharides on simulated microgravity-induced functional inhibition of human NK cells. Carbohydr Polym. 2014; 101: 819-827. https://doi.org/10.1016/j. carbpol.2013.10.021

59. Lee SR, Hwang HJ, Yoon JG, Bae EY, Goo KS, Cho SJ, et al. Antiinflammatory Effect of Lycium Barbarum on Polarized Human Intestinal Epithelial Cells. Nutr Res Pract. 2019; 13(2): 95-104. https:// doi.org/ 10.4162/nrp.2019.13.2.95

60. Juan-García A, Montesano D, Mañes J, Juan C. Cytoprotective effects of carotenoids-rich extract from Lycium barbarum L. on the beauvericininduced cytotoxicity on Caco-2 cells. Food Chem Toxicol. 2019; 133: 110798. https://doi.org/10.1016/j.fct.2019.110798

61. Zhang M, Chen H, Huang J, Li Z, Zhu C, Zhang S. Effect of Lycium barbarum polysaccharide on human hepatoma QGY7703 cells: inhibition of proliferation and induction of apoptosis. Life Sci. 2005; 76(18): 2115-2124. https://doi.org/10.1016/j.lfs.2004.11.009

62. Miao Y, Xiao B, Jiang Z, Guo Y, Mao F, Zhao J, et al. Growth inhibition and cell-cycle arrest of human gastric cancer cells by Lycium barbarum polysaccharide. Med Oncol. 2010; 27(3): 785-790. https://doi.org/ 10.1007/s12032-009-9286-9

63. Suck G, Odendahl M, Nowakowska P, Seidl C, Wels WS, Klingemann HG, Tonn T. NK-92: an 'off-the-shelf therapeutic' for adoptive natural killer cell-based cancer immunotherapy. Cancer Immunol Immunother. 2016; 65(4): 485-892. doi: 10.1007/s00262-015-1761-x 